\title{
TEXTUAL CRITICISM AND TEXT RECONSTRUCTION: APPROACHES TO EARLY RUSSIAN AND WELSH POETRY
}

\author{
ELENA PARINA
}

\section{Contexts of The Tale of Igor's Campaign and The Gododdin Textual Reconstructions}

Textual criticism as discipline was born as means to establish reliable religious texts, especially the Bible. ${ }^{1}$ With almost religious zeal scholars discuss the authenticity of such early poetical texts as the Russian Tale of Igor's Campaign (Slovo o polku Igoreve) and the Welsh Y Gododdin. The history of both of these texts is quite dark. The supposed events described, or in case of The Gododdin rather alluded, date back centuries before we have the earliest extant manuscripts. By coincidence the gap between the campaign of Prince Igor and the MusinPushkin edition equals the time from the supposed battle of Catraeth by estimation of John T. Koch to the date of the manuscript called The Book of Aneirin. Both make about six hundred years. These huge gaps make a fertile field for heated debates on authenticity, dating and authorship of both texts. And, in both cases, one of the outcomes is the creation of a reconstruction for both poetic masterpieces. $^{2}$ Anna Dybo has proposed such a reconstruction for The Tale of Igor's Campaign, whereas John Koch is famous for his hotly debated The Gododdin Ur-Text.

Therefore, at the first glance what we face here is the same work - a reconstruction of an Ur-Text for a poetic work which dates back 600 years from the extant copies. Our task is to compare these two reconstructions and procedures they are acquired by, and our goal is to understand whether these procedures are identical. It probably suits to describe shortly the contents of both books, where these tentative reconstructions are published. Anna Dybo's work is a small part of a two-volume edition, undertaken by the St Petersburg poet and

\footnotetext{
${ }^{1}$ This research is supported by the Russian Academy of Sciences programme "Text in interaction with socio-cultural environment". I would also like to acknowledge the financial support of the Philological Faculty, University of Łódź, received towards the attendance at the conference.

${ }^{2}$ It should be noted that the approach implying the possibility of an Ur-Text reconstruction for a medieval text is by far not the one generally accepted in contemporary research. It could even be said that the whole twentieth century was dedicated to the critique of the Lachmann's methodology, see e.g. a witty review in Cerquiglini (1990). For drawing my attention to this fascinating field I am deeply grateful to Professor Hildegard L. C. Tristram (Freiburg i. Breisgau). However, both authors (discussed in this article) work within the remit of one textological theoretical framework, so that our comparison seems to be justified.
} 
historian Andrej Chernov. The first volume is a luxurious bilingual edition of the Old Russian text in its reconstruction and a Russian translation. The second volume is a 480 page book, consisting of many historical-publicistic articles by Andrej Chernov, an article by Anna Dybo (2006: 419-465), where she minutely explains the principles of the reconstruction applied, and the text version found in the first edition and variant readings. The Ur-Text for The Gododdin is found in the book written by John T. Koch, consisting of a voluminous introduction, dedicated mainly to historical matters, the main part called "Reconstructed text, translation, edited manuscript readings" (Koch 1997: 1-130) and extensive notes to individual poems.

\section{The Tale of Igor's Campaign (Slovo o polku Igoreve)}

Now let us turn to the reconstructions themselves. In the case of The Tale of Igor's Campaign what the scholar has at one's disposal is the following.

\subsection{The Text}

The story of this text transmission is quite a detective novel, to which I can only refer shortly here (for details see (ESPI 1995)). It was published in 1800 (Iroicheskaya Pesn' 1800) and immediately compared by its reviewers with the poetry of Ossian (not describing both as "frauds", but rather referring to the heroic excellence of both). The edition did not bear any names of translators and commentators on the front page, but mentioned that the manuscript belonged to the collector Count Musin-Pushkin. This famous antiquarian did not reveal for a long time the source of his precious catch. He let some renown scholars get acquainted with the manuscript - the famous Russian historian and writer Nikolay Karamzin made many notes from it, a copy was made from the manuscript for the empress Catherine the Great.

The manuscript is supposed to have perished in the Moscow fire of 1812, which made some critics suspect the text soon after this event as a fraud of the eighteenth century. This version was later evolved by scholars of the twentieth century, mainly historians. Their main point was the uniqueness of this text for early Russian literature. It was also noticed that this text has several parallel places with a later text Zadon'schina, also relating to a military campaign, written between 1380 and 1470. For advocates of a late dating for The Tale of Igor's Campaign the latter was written after Zadon'schina was composed, several of them implied it was a mystification of a person highly educated in Slavic studies. It should be added that The Tale of Igor's Campaign was a matter of honour for the Soviet authorities, so that any doubt in its authenticity was considered as antiSoviet, making all the academic discussions impossible. 


\subsection{The Tale's Authenticity and Language}

Despite the attractiveness of this anti-Soviet point of view it was clearly demonstrated by linguists like Roman Jakobson (1966) and most recently Andrey Zaliznyak (2004) that the monument dates back to the late twelfth - the early thirteenth century. What made them come to such a conclusion was the bulk of linguistic evidence. Although The Tale of Igor's Campaign is an unprecedented poetic work for Old Russian literature, there are several contemporary monuments - annals, one of which relates to this very campaign dating it to 1185 , and other documents. The language of the annals is highly influenced by Church Slavonic, but recent studies have brought to us other exciting material for comparison - birch inscriptions, mainly everyday letters, written in the spoken language datable between eleventh - fourteenth centuries (Zaliznyak 1995). Therefore a scholar has at his disposal a representative corpus of Old Russian monuments from the eleventh century onwards; Russian philology knows fairly well about the dialectal variations from these texts; and, furthermore, there is a huge corpus of other Slavonic languages to refer to in case of hapaxes. The main direction of arguments for The Tale of Igor's Campaign early dating is a demonstration that the language of this monument corresponds to that of definitely early inscriptions, documents etc. not only in phonetics and lexicon, but also in such fine syntactic and morphological peculiarities, as in the use of clitics or dual number, that it could not have been imitated at the stage of knowledge which existed in the eighteenth century.

Anna Dybo, a former student of Andrey Zaliznyak, "yields to temptation" in her own words to present a reconstructed text for The Tale of Igor's Campaign (Dybo 2006). She approaches the text in the Musin-Pushkin edition as a layered structure, removing layer by layer changes introduced by scribes. I shall not be able to refer to this analysis in detail; fortunately it is minutely described in her article, where one can follow it.

The upper layer of these errors (i.e. changes introduced by copying a previous text) is recognised as "mistakes" of a person with knowledge of the standard eighteenth century Church Slavonic language. Among those is, for example, a sporadic use of letter $<i>$ which is absent in earlier manuscripts (Dybo 2006: 422).

The second layer of changes is defined on historic-dialectological grounds as a work of a fifteenth - sixteenth century scribe from Pskov or Byelorussia. These changes occur both in orthography and phonology, as well as in morphology. In orthography we see sporadic spellings like $\langle\kappa u\rangle,\langle z u\rangle$ vs. $\langle\kappa b l\rangle$, $\langle 2 b l>$. The first edition and the copies of the extinct manuscript often vary in these cases. It was shown by A. Zaliznyak (2004: 88) that these discrepancies, as well as the growing number of spellings $\langle\kappa u\rangle$, grow as the text goes further. This tendency could be explained in a natural way if one thinks about a copyist at work: first he was very careful, but then as his weariness grew, he started writing 
in a way which was normal for the phonetics contemporary to him instead of copying the old $\langle\kappa b l\rangle,\langle 2 b l\rangle$ showing no palatalisation. The same holds true for reduced vowels: a complex statistical analysis of the text shows that errors in reduced vowels (that is the use of $\langle b\rangle$ or $\langle\boldsymbol{b}\rangle$ in positions, where in earlier texts one would expect the opposite) occur much more often towards the end of the text, i.e. when the scribe gets tired. The analysis of Smolensk documents reveals that it is exactly the type of graphical changes we can expect to occur (Dybo 2006: 432-436). The same is done on the morphological level: e.g. for flexions in adjectival declension, personal pronouns etc.

By removing these layers one gets a text characterised by features in graphic and orthography typical for Smolensk-Polozk dialects of the twelfth thirteenth centuries.

As a result of this linguistic procedure one sees considerable improvement of poetic structure in several fragments. A reconstructed text is presented cautiously as an attempt to show what a possible protograph could have looked like, not a transcription of the text's phonetics. One major deviation of a possible protograph is the division of the text into poetic lines and the word division, both depending on text interpretation and certainly absent from the manuscript. This deviation is however explicitly mentioned (Dybo 2006: 422). The scholar concludes her explanatory article by the following words:

I do not consider by no means absolutely irrefutable even those decisions, which we accepted above in quite a firm belief. But they were at least accepted uniformly and were validated as far as possible at every step by data of historical and synchronous dialectology, as well as by intrasystematic text parameters.

(Dybo 2006: 464, my trans.)

\section{The Gododdin: The Text and its Reconstruction}

Now let us turn to The Gododdin. The text at scholar's disposal is contained only in one manuscript usually called The Book of Aneirin datable on palaeographic grounds to the middle of the thirteenth century (Huws 2000: 74). The text is not an epic narrative - there are four independent poems and 130 shorter poems or awdlau - 88 in hand A, 42 in hand B. Awdlau in versions A and B have several parallels, moreover the later version (as shown in Isaac 1993) falls apart into two ( $\mathrm{B}^{1}$ (awdlau 1-23) and $\mathrm{B}^{2}$ (awdlau 24-42)), so some poems are in fact three versions of one text for which John Koch proposes a possible Ur-Text. Graham Isaac points out that certain orthographic and phonetic archaisms mainly in part $\mathrm{B}^{2}$ allow to propose for certain awdlau that they were certainly written down already by the tenth century (Isaac 1999a: 65). D. Simon Evans (1978: 87) was a bit more permissive and pointed out that we have no linguistic evidence to lead us behind the ninth century.

Many of the awdlau begin with words gwyr a aeth gatraeth 'men went to Catraeth' and it was an established view by the middle of the twentieth century to 
consider the whole text to be written by the legendary bard Aneirin and dedicated to a battle with Anglo-Saxons in the south of the modern-day Scotland, which happened in the sixth century (the classical edition of this text done by Ifor Williams (1938) already reflects this view). There is no record of such an event in any chronicle, nevertheless, many scholars thought of this text as composed quite soon after the battle, transmitted orally, then written down at some stage either still in the Old North i.e. outside of Wales or else already in Wales (Jarman 1976: 68). This is not the only possible explanation for this text, as Graham Isaac (1999b: 143-7) points out. Anyway, for John T. Koch, I cite, "reconstruction is the most concise and explicit way of facing the implications of an attribution and dating which are today widely accepted and of reconciling the internal evidence of the text itself” (Koch 1997: xi). He describes his methodology as follows:

We cannot recover the original forms of the elegies of $\ddot{E}$ Gododin by mere comparison of the extant texts in BA. Too much time and linguistic and orthographic evolution has taken place between the composition of the older elegies and the writing of our copy, and the variant readings are so few. So, as well as taking textual criticism as far as I could, linguistic reconstruction and metrical features have been used to restore the awdlau. In other words, in the light of dating evidence and the hypothetical historical framework set above, the individual verses have been reconstructed according to what is otherwise known of the development of the Brittonic languages.

(Koch 1997: cxxvii)

To present his reconstruction J. Koch uses “conventions of early Neo-Brittonic spelling (rather than in phonetic or phonemic symbols)” (Koch 1997: cxxviii) to which he adds his own diacritics to avoid ambiguity. Strangely enough he uses the same system to present the manuscript itself - this decision was criticised in (Padel 1998: 52; Isaac 1999b: 139).

As the author uses comparative linguistic methods along with textual criticism, he relies on a list of phonetic changes that occurred from the sixth to twelfth century (Koch 1997: cxxviii). The results of such changes are abolished for the reconstruction. This list of dated phonetic changes is based on a famous work of Kenneth Jackson Language and History in Early Britain (1953). The problem with these datings are, as noted by Gr. Isaac, that K. Jackson was a staunch defender of an early composition of The Gododdin (cf. the title of his edition The Gododdin: The Oldest Scottish Poem (Jackson 1969)), so that LHEB was written "with a hidden aggenda" of providing evidence for the argument that "Welsh is old enough as a language for poems composed in northern Britain towards the end of the sixth century to survive intact to appear in Middle Welsh guise in the thirteenth century” (Isaac 1996: 8). As for Koch's reconstruction, unfortunately unlike the case of The Tale of Igor's Campaign we do not get an explicit description of such a procedure, neither do we get a sketch of the 
grammar for this archaic language - the scholar refers to his Grammar of Old Welsh, but it did not appear in the last ten years that passed since the publication. Some smaller text part reconstructions were approved by A. Korolev and many other scholars (see, e.g. Kalygin \& Korolev 1989: 210), as they showed a considerable metrical improvement. For Oliver Padel this was a great achievement too, but in the case of the Ur-Text this argument would be indubitable if statistical analysis could show that these changes make much more sense for a presumably sixth century text in contrast to a definitely later text, e.g. Armes Prydein (Padel 1998: 53-54).

What is of crucial importance here, is that this text is supposed to be written and therefore is reconstructed not in Old Welsh, which is attested, though the corpus is not a huge one (see Falileyev 2008), but in "Archaic Neo-Brittonic". The only monuments that definitely date back to this period are inscriptions, consisting mainly of isolated proper nouns. As for their number, 371 Celtic inscriptions of Britain are dated by P. Sims-Williams to circa 400-1200 (SimsWilliams 2003), so the evidence for reconstructing syntax and morphology for this language is quite insufficient. The longer texts, like those attributed to 'historic Taliesin' by I. Williams, preserved also only in manuscripts written down in the Middle Welsh period, which makes them unsuitable as arguments for The Gododdin early dating. ${ }^{3}$

Our observations can be presented in the form of the following table (all the dates are taken from the reviewed works, our only additions are the data on the documents contemporary at the time the suggested Ur-Text was composed):

Table 1

\begin{tabular}{|c|c|c|}
\hline & Y Gododdin & The Tale of Igor's Campaign \\
\hline Event dating & 570 & 1185 \\
\hline Earliest text dating & 500 AD for some stanzas & 1100 \\
\hline $\begin{array}{c}\text { Earliest surviving } \\
\text { manuscript }\end{array}$ & ca. 1250 & 1795 \\
\hline Contemporary monuments & inscriptions & $\begin{array}{c}\text { annals, documents, birch } \\
\text { inscriptions }\end{array}$ \\
\hline Language & Archaic Neo-Brittonic & $\begin{array}{c}\text { Old Russian (Smolensk- } \\
\text { Polozk dialect) }\end{array}$ \\
\hline
\end{tabular}

\footnotetext{
${ }^{3}$ This issue is one of the hottest topics in Welsh philology, see overviews in Kalygin \& Korolev (1989: 208-211); Isaac (2002); Falileyev fc.
} 


\section{Conclusion}

The late Russian Celticist, Andrej Korolev, once wrote an astonishing paper on philological methods in Celtic philology, in which he discussed the importance and possibility of reconstruction for early texts. He described two methodologies to editing texts as expedient for Celtic philology: (1) "the reproduction of the manuscript as written by the scribe [that] reflects the manuscript reality", and (2) "a reconstruction [that] reflects a reality of a certain language stage" (Korolev 1988: 137, my trans.). Moreover, he criticised several editions which blindly followed the principles of textual criticism and allowed for a proposed Ur-Text both the archaic and obviously the newer forms simultaneously. As an example to follow, he referred to the editions of Early Slavic texts in which the changes incorporated into the texts by later scribes were removed. In this way, the work of Anna Dybo meets one of the strictest requirements set for the contemporary philology by one of the most austere scholars in the Celtic field. ${ }^{4}$

The vehemence of debates of those supporting an early date of both texts against those pleading for a much later date reveals common point in these discussions: it is mostly a question of Machtkampf between the historians and the linguists. As mentioned above, the reconstruction of Anna Dybo is published in a volume, consisting mainly of her colleague Andrey Chernov's historical and philological interpretations of the text that are full of highly interesting suggestions on the text authorship, provenance, the place of the battle etc. All of this does not affect the text reconstruction proposed by Anna Dybo, based mainly on comparison with other monuments. In the case of John Koch's attempt, the text reconstruction, its stemmas and the fascinating history of the battle itself and that of the text transmission as he presents them are all very much interwoven. The reliable contemporary documents are too scarce, and yet it is hard to dwell upon the poems' language morphology and their syntax. Like Anna Dybo, I believe that linguistics resembles an exact science like no other branch of the humanities. Therefore, Anna Dybo's work may be defined as an audacious protograph reconstruction, whereas John Koch's work is, exactly as the author put it, a "concise and explicit way" to present his historical views.

Institute of Linguistics, Moscow,

Russia

\footnotetext{
${ }^{4}$ We should add in passing that Celtic philology is aware of editions which are, in their methodological approach, not very far from the one described for The Tale of Igor's Campaign. In different ways, Séamus Mac Mathúna’s Immram Brain (Mac Mathúna 1985) and Kim McCone’s Echtrae Chonnlai (McCone 2000) can be seen as such works.
} 


\section{Abbreviations}

BA - The Book of Aneirin

ESPI - Enziklopediya Slova o polku Igoreve [Encyclopedia of the Tale of Igor's Campaign], Saint Petersburg: Institut russkoj literatury (Pushkinskij dom), 1995, electronic version at http://feb-web.ru/feb/slovenc/es/

LHEB - Language and History in Early Britain (Jackson 1953)

\section{References}

Cerquiglini, B., 1990, Éloge de la variante. Histoire critique de la philologie, Paris: Seuil.

Dybo, A. V., 2006, 'Rekonstrukziya drevnerusskogo texta. Problema rekonstrukzii pervonachal'nogo texta 'Slova o polku Igoreve' $\mathrm{s}$ lingvisticheskoj tochki zrenija' ['Reconstruction of the Old Russian Text. Problem of Reconstruction of the Original "Tale of Igor's Campaign” Text from a Linguistic Point of View'], in: Chernov, A., Xroniki iznanochnogo vremeni: "Slovo o polku Igoreve": text i ego okrestnosti [Chronicles of Dark Times. The Tale of Igor's Campaign: Text and its Environment], St Petersburg: Vita Nova, 389-464.

Evans, D. S., 1978, 'Iaith Y Gododdin', in: Bromwich, R., Jones, B. R., eds., Astudiaethau ar yr Hengerdd, Caerdydd: Gwasg Prifysgol Cymru, 72-88.

Falileyev, A. I., 2008, Le Vieux-Gallois, en collab. avec H. L.C. Tristram pour la réd., trad. Y. le Berre, Potsdam: Universitätsverlag Potsdam.

Falileyev, A. I., fc., Drevnejshaya vallijskaya poeziya [Early Welsh Poetry], St Petersburg.

Huws, D., 2000, Medieval Welsh Manuscripts, Cardiff: University of Wales Press.

Iroicheskaya Pesn' o pokhode na polovzev udel'nogo knyazya NovagorodaSeverskogo Igorya Svyatoslavicha [Heroic Tale of Cuman Campaign of the Novgorod-Severskij Prince Igor Svyatoslavich], 1800, Moscow.

Isaac, G. R., 1993, 'Canu Aneirin Awdl LI', Journal of Celtic Linguistics 2, 6591.

Isaac, G. R., 1996, The Verb in the Book of Aneirin. Studies in Syntax, Morphology and Etymology, Tübingen: Max Niemeyer Verlag.

Isaac, G. R., 1999a, 'Readings in the History and Transmission of the Gododdin', Cambrian Medieval Celtic Studies 37, 55-78.

Isaac, G. R., 1999b, 'The Gododdin of Aneirin - adolygiad', Llên Cymru 22, 138-160. 
Isaac, G. R., 2002, 'Scholarship and Patriotism: the Case of the Oldest Welsh Poetry', Studi Celtici 1, 67-81.

Jackson, K., 1953, Language and History in Early Britain: A Chronological Survey of the Brittonic Languages, First to Twelfth Century A.D., Edinburgh: University of Edinburgh Press.

Jackson, K., 1969, The Gododdin: The Oldest Scottish Poem, Edinburgh: University of Edinburgh Press.

Jakobson, R., 1966, 'La Geste du Prince Igor’’, in: Jakobson, R., Selected Writings, vol. IV, The Hague-Paris, 106-300.

Jarman, A. O. H., 1976, ‘Aneirin - The Gododdin’, in: Jarman, A. O. H., Huws, Gw. R., eds., A Guide to Welsh Literature, vol. I, Cardiff: University of Wales Press, 68-80.

Koch, J. T., 1997, The Gododdin of Aneirin: Text and Context from Dark-Age North Britain, Cardiff: University of Wales Press.

Korolev, A. A., 1988, 'Filologicheskie metody v issledovanii istorii keltskix yazykov' ['Philological Methods in Historical Studies of Celtic Languages'], in: Sravnitel'no-istoricheskoe izuchenie yazykov raznyx semey, Moscow: Nauka, 119-138.

Mac Mathúna, S., 1985, Immram Brain. Bran's Journey to the Land of Women, Tübingen: Niemeyer.

McCone, K., 2000, Echtrae Chonnlai and the Beginnings of Vernacular Narrative Writing in Ireland: a Critical Edition with Introduction, Notes, Bibliography and Vocabulary, Maynooth: Department of Old and Middle Irish, National University of Ireland.

Padel, O., 1998, 'A New Study of the Gododdin', Cambrian Medieval Celtic Studies 35, 45-56.

Sims-Williams, P., 2003, The Celtic Inscriptions of Britain. Phonology and Chronology, c. 400-1200, Oxford: Blackwell.

Williams, I., 1938, Canu Aneirin: gyda rhagymadrodd a nodiadau, Aberystwyth: University of Wales Press.

Zaliznyak, A. A., 1995, Drevnenovgorodskij dialekt [The Old Novgorod Dialect], Moscow: Yazyki russkoj kul'tury.

Zaliznyak, A. A., 2004, "Slovo o polku Igoreve": vzglyad lingvista [The Tale of Igor's Campaign from Linguist's Point of View], Moskow: Yazyki slavyanskoj kul'tury. 